\title{
A Geophysical Investigation of Resistivity and Groundwater Quality near a Corporate Solid Waste Dump
}

\author{
Susaiappan Sidhardhan ${ }^{1 *}$, Somanathan Adishkumar², Duraipandian Jayganesh ${ }^{3}$ \\ 'Department of Civil Engineering, Government College of Engineering, Tirunelveli, India \\ ${ }^{2}$ Department of Civil Engineering, VOC University College of Engineering, Anna University, Tuticorin, India \\ ${ }^{3}$ Department of Civil Engineering, University College of Engineering, Anna University, Ramanathapuram, India
}

Received: January 21, 2015

Accepted: August 27, 2015

\begin{abstract}
This paper presents a survey of resistivity and groundwater quality around the solid waste dumpsite of Tirunelveli Municipal Corporation at Ramaiyanpatti in the state of Tamilnadu, India. Water samples were collected and analysed for physico-chemical parameters in the study area. Electrical resistivity surveys were carried out in the study area. The physico-chemical analysis of groundwater as well as geophysical investigation revealed that there are considerable impacts of solid waste dumpsite leachate in the groundwater aquifer. To minimize the impact of such leachate of a dumpsite on groundwater quality and the environment in general, it is necessary to properly design, construct, and manage the dumpsite by engineering principles.
\end{abstract}

Keywords: dumpsite, resistivity, physico-chemical parameters, groundwater pollution, aquifer, leachate

\section{Introduction}

Rapid urbanization has caused numerous hazards and poses serious environmental threats to surroundings and nearby residents by solid waste disposal dumpsites [1]. More often, in some cities, the generated huge amount of solid waste of cities is just dumped in open yards without geo-membrane lining the ground to protect from infiltration and transportation of the contaminants of the solid waste into the soil and the groundwater. Prior processing of the waste as per accepted means of solid waste management is also not being done [2, 3]. The leachates from these open dumps contain many substances that can contaminate the groundwater at large and hence make the groundwater unsuitable for domestic and agricultural purposes [4]. The impact of such studies on groundwater quality can be assessed by analysing the physico-chemical parameters at a number of well points present in the study area.

*e-mail: sidhardhant@yahoo.co.in
The study area under investigation, located at Ramaiyanpatti in Tirunelveli Municipal Corporation, is naturally an undulating area used for disposal of urban solid waste for the last 15 years through the practice of open dumping without application of engineering principles that protect the environment against pollution. In addition to the solid waste dump yard, a low-cost sewage treatment plant (stabilization ponds) is also present in the study area for treating 24 million litres per day (MLD) Municipal Corporation sewage. The present study is undertaken to determine the physico-chemical parameters in the groundwater due to the discharge of leachate from the open dumpsite to the underlying groundwater aquifer system in the area.

\section{Study Area}

The study area is located at Ramaiyanpatti on the Northwestern side of Tirunelveli city (Fig. 1). Tirunelveli is the sixth largest city in the state of Tamilnadu, with an area of $108.65 \mathrm{sq}$. $\mathrm{km}$ and a population of 475,000 (according to 
the 2011 census) and a floating population of more than 50,000 [5]. It is located at $8^{\circ} 45^{\prime} 04^{\prime \prime}$ north latitude and $77^{\circ} 41^{\prime} 31^{\prime \prime}$ east longitude. The Tamirabarani River flows through the corporation area. It is well connected with road and rail. The city is a hub for various businesses, including retail and wholesale markets.

Tirunelveli enjoys a subtropical climate. The period from May to June is generally hot and dry. The weather is pleasant during the period from December to January. Relative humidity is on an average between 79 and $84 \%$. The daily mean minimum temperature is $22.9^{\circ} \mathrm{C}$ and maximum temperature is $33.5^{\circ} \mathrm{C}$ [6].

The open dumping site is surrounded by a road in the eastern side and Megamudaiayarkulam tank bund in the western side. The terrain of the disposal site slopes eastward and is in the region of Megamudaraiyarkulam anicut. An agricultural field (paddy field) and residential area are situated adjacent to the site. In addition, the sewage treatment plant for Tirunelveli Corporation of capacity 24 MLD is situated in the southwest corner of the dumpsite.

\section{Composition and Quantity of Solid Wastes of the Study Area}

It is observed that the entire area of the dump site is filled with solid waste without any systematic and scientific manner as laid down by engineering principles. The solid wastes are not covered by a soil layer so as to enable the decomposition of organic matter for every subsequent disposal. The bottommost layer of the open dumpsite is not properly lined and hence there is no provision for the collection of leachate and gas produced. It is found that the depth of solid waste varies from $2.2 \mathrm{~m}$ to $2.8 \mathrm{~m}$ and average depth is $2.5 \mathrm{~m}$. It is observed from the past history that the solid wastes of the open dumpsite caught fire then and there, and this fire continues for two or three days twice in year. The reason or route cause for the fire is unknown.

By visual observation of solid waste, it is found that it consists of various constituents like paper, organic matter, metals, glass, ceramics, plastics, textiles, dirt, and wood. The composition of solid waste was determined by sorting waste into components for weighing to determine the percentage of each component. The composition of solid waste (\% by weight) consisted of $68.41 \%$ bio degradable; $8.98 \%$ plastic; $3.98 \%$ paper; $1.62 \%$ metal, glass, and rubber; and $17.10 \%$ inert with sand and debris. The per capita generation of solid waste in 2011 was $0.32 \mathrm{~kg}$ and would be around 160 metric tons daily.

\section{Materials and Methods}

Geophysical prospecting has been carried out to delineate the subsurface condition of the study area. One of the suitable geophysical prospects, called electrical methods, is used for the purpose of exploration [7]. Vertical electrical sounding using an SSR MP-ATS (signal stacking digital resistivity meter) has been done at 10 locations selected randomly toward natural sloping terrain, i.e. the eastern side of the dump area. In the electrical method

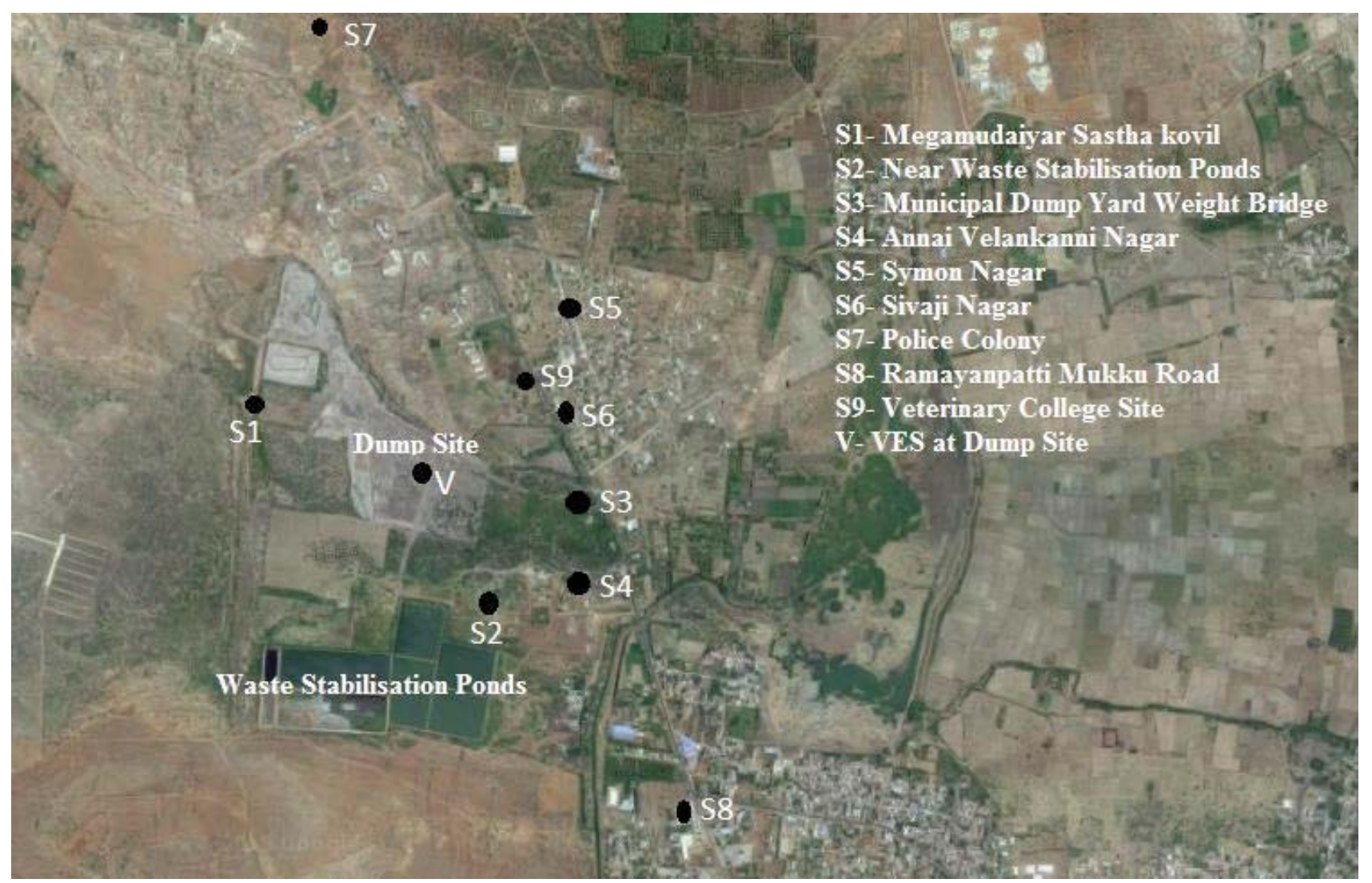

Fig. 1. Locations of sampling and VES points. 
Schlumberger's array is used for electrode configuration. Four electrodes were used as shown in Fig. 2. An electrical field is created using current electrode $\mathrm{C} 1 \mathrm{C} 2$, which is fixed at a distance $\mathrm{AB}(\mathrm{AB} / 2$ is the depth covered). Using P1P2 electrodes the potential difference was measured (resistivity value $R$ ) between the points MN. Reading $R$ is multiplied by a depth constant $(K)$ to obtain the resistivity value $(\rho)$ :

$$
\rho=K \times R
$$

...where: $K=\left[(\mathrm{AB} / 2)^{2}-(\mathrm{MN} / 2)^{2}\right] \times 3.14 / 2(\mathrm{MN} / 2)$

The resistivity value is inversely proportional to the conductivity of the subsurface formation (rocks and groundwater) [8-10]. Likewise, the resistivity of the area decreases as the presence of pollutants increases.

\section{Groundwater Sample Analysis}

Groundwater samples were collected from bore wells at nine locations around the dump site. Samples were collected in each bore well on three different occasions within a period of one week. The samples were tested for various physico-chemical parameters such as $\mathrm{pH}$ value, total dissolved solids (TDS), electrical conductivity (EC), total hardness $(\mathrm{TH})$, total alkalinity $(\mathrm{AL})$, acidity $(\mathrm{AC})$, sulphates $\left(\mathrm{SO}_{2}^{-}\right)$, chloride $\left(\mathrm{Cl}^{-}\right)$, fluoride $\left(\mathrm{F}^{-}\right)$, iron $\left(\mathrm{Fe}^{++}\right)$, and bio-chemical oxygen demand (BOD) as per standard methods [11-12]. The results are tabulated in Table 1.

\section{Results and Discussion}

The acquired apparent resistivity data set at nine groundwater sampling locations and dumpsite are presented in Table 2. The results of the interpretation of vertical electrical sounding (VES) data revealed that different geoelectrical layers do exist and are expressed in terms of their resistivities at specified depths in the study area [10]. A total of three to four geo-electrical layers were delineated with varying curve types, reflecting the lithological variations with depth $[13,14]$. The nature of the curve types suggests that the measured resistivity varies with depth of investigation in the study site. The topmost layer consist of dry soil. The subsurface formation consists of dry soil, followed by a weathered zone, weathered/fractured zone, and compact rock.
The interpretation indicates that the weathered zone constitutes the main aquifer unit. The VES results show that the depth of groundwater table in the study area is about 4.5 to $7.5 \mathrm{~m}$. The result of electrical prospecting's lowest resistivity values are shown at the dump site, at Shivaji Nagai, and at Annaivelakani Nagai, and are $6.5 \Omega \mathrm{m}, 4.03 \Omega \mathrm{m}$, and $17.3 \Omega \mathrm{m}$, respectively. Highest resistivity values were observed at points where there is no contamination (i.e., far from the western side of the dumpsite), such as the police colony and veterinary college, and are $40.21 \Omega \mathrm{m}, 156.1$ $\Omega \mathrm{m}$, and $70.33 \Omega \mathrm{m}$, respectively. Groundwater not affected by leachate intrusion was indicated by high resistivity values. Comparatively lower resistivity has been observed toward the northeastern side of the dumpsite. The direction of contaminant transport has been identified as in the northeastern direction of the dump site using the electrical resistivity method.

Higher values of the measured parameters from the physico-chemical analysis of water samples in the existing wells indicate that the contaminations of the groundwater mainly result from infiltrations of solid waste leachate, and this fact is also confirmed by geophysical data [15].

Urban solid waste is heterogeneous in nature and consists of a number of different materials derived from various types of activities. The major constituents are biodegradable, inert, sand, and debris materials. Other materials like metal, glass, rubber, plastic, and paper are generally present in different proportions, and their relative proportions depend on local factors. The composition of solid waste is essential for providing the basic data on which the planning of the solid waste management system depends. It includes selection of appropriate equipment and technology and suitable processing, recovery, and recycling.

The mean values of the water analysis results obtained from each bore well are shown in Table 1 . The standards for drinking and domestic use for the various parameters tested were taken from the Bureau of Indian Standard Specifications (IS-10500:1995) [16].

The $\mathrm{pH}$ values for all sampling wells were at the lessthan-desirable limit of 6.5-8.5. Total hardness of the groundwater is very high: $1,368 \mathrm{mg} / 1,1,068 \mathrm{mg} / 1$, and $1,090 \mathrm{mg} / \mathrm{l}$ in the samples collected from Shivaji nagar, Annaivelakani nagar, and the northeastern side of the stabilisation point, respectively, when compared to the standards prescribed as $300 \mathrm{mg} / \mathrm{l}$ measured as $\mathrm{CaCO}_{3}$ for drinking.

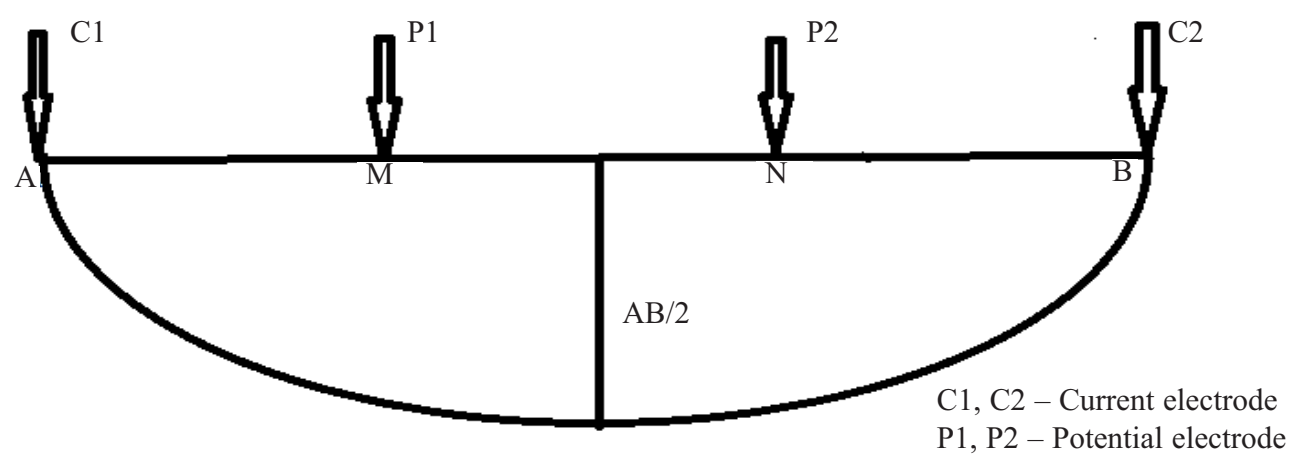

Fig. 2. Electrode configuration. 
Table 1. Physico-chemical characteristic of groundwater for sampling wells.

\begin{tabular}{|c|c|c|c|c|c|c|c|c|c|c|}
\hline \multirow{2}{*}{ No. } & \multirow{2}{*}{ Parameters } & \multicolumn{9}{|c|}{ Sampling station (wells) } \\
\hline & & S1 & S2 & $\mathrm{S} 3$ & S4 & S5 & S6 & S7 & S8 & S9 \\
\hline 1 & Location & $\begin{array}{l}\text { Mega- } \\
\text { mudariyar } \\
\text { Satha }\end{array}$ & $\begin{array}{c}\text { Near Waste } \\
\text { Water } \\
\text { Treatment } \\
\text { Plant }\end{array}$ & $\begin{array}{l}\text { Muncipal } \\
\text { Weight } \\
\text { Bridge }\end{array}$ & $\begin{array}{c}\text { Annai Vela } \\
\text { Kaninagar }\end{array}$ & $\begin{array}{l}\text { Symon } \\
\text { Nagar }\end{array}$ & $\begin{array}{l}\text { Sivaji } \\
\text { Nagar }\end{array}$ & $\begin{array}{l}\text { Police } \\
\text { Colony }\end{array}$ & $\begin{array}{c}\text { Ramaya } \\
\text { Nipatti } \\
\text { Mukku } \\
\text { Road }\end{array}$ & $\begin{array}{l}\text { Veterinary } \\
\text { College site }\end{array}$ \\
\hline 2 & Latitude & $8^{\circ} 45^{\prime} 51.93^{\prime \prime} \mathrm{N}$ & $8^{\circ} 45^{\prime} 32.72^{\prime \prime} \mathrm{N}$ & $8^{\circ} 45^{\prime} 41.32^{\prime \prime} \mathrm{N}$ & $8^{\circ} 45^{\prime} 33.26^{\prime \prime} \mathrm{N}$ & $8^{\circ} 46^{\prime} 01.47^{\prime} \mathrm{N}$ & $8^{\circ} 45^{\prime} 50.38^{\prime \prime} \mathrm{N}$ & $8^{\circ} 46^{\prime} 32.81^{\prime \prime} \mathrm{N}$ & $8^{\circ} 45^{\prime} 14.12^{\prime \prime} \mathrm{N}$ & $8^{\circ} 45^{\prime} 53.96^{\prime \prime} \mathrm{N}$ \\
\hline 3 & Longitude & $77^{\circ} 40^{\prime} 35.69^{\prime \prime} \mathrm{E}$ & $77^{\circ} 40^{\prime} 59.93^{\prime \prime} \mathrm{E}$ & $77^{\circ} 41^{\prime} 09.13^{\prime \prime} \mathrm{E}$ & $77^{\circ} 41^{\prime} 06.25^{\prime \prime} \mathrm{E}$ & 77²41'07.37’'E & 77041'06.47’'E & $77^{\circ} 40^{\prime} 39.75^{\prime \prime} \mathrm{E}$ & $77^{\circ} 41^{\prime} 17.11^{\prime \prime} \mathrm{E}$ & $77^{\circ} 41^{\prime} 01.28^{\prime \prime} \mathrm{E}$ \\
\hline 4 & $\mathrm{pH}$ & 7.48 & 6.94 & 7.25 & 7.04 & 7.54 & 6.86 & 7.39 & 7.53 & 7.3 \\
\hline 5 & $\begin{array}{l}\text { Conductivity } \\
\text { EC }(\mathrm{mS} / \mathrm{cm})\end{array}$ & 0.69 & 3.98 & 2.51 & 3.21 & 1.02 & 3.92 & 0.83 & 2.07 & 2.04 \\
\hline 6 & TDS (mg/l) & 540 & 3,070 & 2,000 & 2,300 & 810 & 3,050 & 700 & 1,580 & 1,500 \\
\hline 7 & $\begin{array}{c}\text { Total } \\
\text { Hardness } \\
(\mathrm{TH})(\mathrm{mg} / \mathrm{l})\end{array}$ & 296 & 1,090 & 800 & 1,068 & 376 & 1,368 & 350 & 728 & 688 \\
\hline 8 & $\begin{array}{c}\text { Chloride } \\
\left(\mathrm{Cl}^{-}\right)(\mathrm{mg} / \mathrm{l})\end{array}$ & 80 & 800 & 620 & 770 & 205 & 895 & 250 & 485 & 495 \\
\hline 9 & $\begin{array}{l}\text { Alkalinity } \\
\text { (Al) (mg/l) }\end{array}$ & 845 & 686 & 764 & 776 & 432 & 696 & 640 & 496 & 648 \\
\hline 10 & $\begin{array}{c}\text { Acidity } \\
\text { (AC) (mg/l) }\end{array}$ & 16 & 16 & 10 & 16 & 7 & 16 & 10 & 13 & 14 \\
\hline 11 & $\begin{array}{c}\text { Sulphate } \\
\left(\mathrm{SO}_{2}^{-}\right)(\mathrm{mg} / \mathrm{l})\end{array}$ & 240.3 & 146.5 & 227.1 & 45.4 & 59.3 & 146.5 & 45.5 & 77.6 & 87.0 \\
\hline 12 & $\begin{array}{l}\text { Fluoride } \\
\left(\mathrm{F}^{-}\right)(\mathrm{mg} / \mathrm{l})\end{array}$ & 0.30 & 0.26 & 0.30 & 0.40 & 0.24 & 0.26 & 0.20 & 0.15 & 0.16 \\
\hline 13 & $\begin{array}{c}\operatorname{Iron}\left(\mathrm{Fe}^{+}\right) \\
(\mathrm{mg} / \mathrm{l})\end{array}$ & 0.15 & 0.10 & 0.20 & 0.05 & 0.05 & 0.10 & 0.05 & 0.05 & 0.15 \\
\hline 14 & BOD (mg/l) & 2.40 & 4.60 & 2.40 & 6.20 & 2.90 & 4.60 & 2.00 & 3.24 & 4.03 \\
\hline
\end{tabular}

Table 2. Vertical electrical sounding for sampling stations inside dumpsite.

\begin{tabular}{|c|c|c|c|c|c|c|c|c|c|c|c|}
\hline \multirow{2}{*}{ No. } & \multirow{2}{*}{$\frac{\mathrm{AB} / 2}{\mathrm{M}}$} & \multirow{2}{*}{$\begin{array}{l}\text { Dump-site } \\
\text { VES (V) } \Omega \mathrm{m}\end{array}$} & \multicolumn{9}{|c|}{$\mathrm{VES} \Omega \mathrm{m}$} \\
\hline & & & S1 & S2 & $\mathrm{S} 3$ & S4 & S5 & S6 & S7 & S8 & S9 \\
\hline 1 & 1.5 & 11.25 & 81.13 & 28.23 & 3.79 & 12.07 & 26.77 & 29.83 & 58.31 & 18.79 & 50.80 \\
\hline 2 & 3 & 5.33 & 84.18 & 40.24 & 1.96 & 20.67 & 52.28 & 27.14 & 96.66 & 27.92 & 60.60 \\
\hline 3 & 4.5 & 6.76 & 59.98 & 36.13 & 27.62 & 19.19 & 36.17 & 26.08 & 131.85 & 39.40 & 70.33 \\
\hline 4 & 6 & 6.50 & 40.21 & 48.78 & 4.03 & 27.70 & 17.31 & 29.70 & 156.10 & 51.96 & 80.51 \\
\hline 5 & 7.5 & 7.42 & 31.98 & 56.20 & 92.14 & 32.11 & 30.18 & 36.89 & 177.44 & 61.08 & 140.10 \\
\hline 6 & 9 & 6.69 & 36.90 & 48.42 & 31.08 & 39.52 & 34.62 & 33.43 & 164.45 & 72.58 & 190.45 \\
\hline 7 & 10.5 & 9.44 & 40.70 & 54.21 & 62.50 & 38.78 & 35.57 & 40.26 & 207.54 & 68.43 & 240.92 \\
\hline 8 & 12 & 11.25 & 45.81 & 58.42 & 73.97 & 37.01 & 39.95 & 45.12 & 265.80 & 77.62 & 220.46 \\
\hline 9 & 13.5 & 12.77 & 96.71 & 61.76 & 892.94 & 35.55 & 42.60 & 46.90 & 304.31 & 84.41 & 270.50 \\
\hline 10 & 15 & 14.63 & - & 65.21 & 492.53 & 38.38 & 44.97 & 50.59 & 348.00 & 89.46 & 330.78 \\
\hline 11 & 16.5 & 14.68 & - & 57.61 & 156.15 & 49.42 & 46.91 & 47.76 & 329.98 & 94.90 & 420.86 \\
\hline 12 & 18 & 15.87 & - & 60.72 & 145.11 & 52.17 & 49.32 & 48.06 & 388.98 & 105.73 & 500.60 \\
\hline 13 & 19.5 & 17.65 & - & 66.47 & 104.06 & 54.34 & 55.88 & 50.24 & 434.95 & 110.19 & 580.73 \\
\hline
\end{tabular}


The presence of this total hardness in water is objectionable from the view point of scale formation when heating, and it also consumes more detergents while washing. However, Dzik [17] has reported an inverse relationship between water hardness and cardiovascular disease.

Bio-chemical oxygen demand (BOD) values ranged between $2.00-6.20 \mathrm{mg} / \mathrm{l}$ in the study area. The BOD content in the ground water indicates the presence of organic content. The BOD values in the Shivaji nagar, Annaivelakani nagar, and the western side of the stabilization pond are $4.60 \mathrm{mg} / \mathrm{l}, 6.20 \mathrm{mg} / \mathrm{l}$, and $4.6 \mathrm{mg} / \mathrm{l}$, respectively - indicating that the groundwater is polluted with organic pollutant.

Total dissolved solids are a measure of total inorganic substances dissolved in water [18]. The total dissolved solids in Shivaji nagar, Annaivelakani nagar, and the point near the northeastern side of the waste stabilization ponds are very high at 3,050 mg/1, 2,300 mg/l, and 3,070 mg/l. These values are very high when compared to the drinking standards desirable limits of $500 \mathrm{mg} / \mathrm{l}$. Higher dissolved solids concentrations reduce the palatability of water and may cause gastrointestinal irritation [19].

The electrical conductivity values are observed to be high at Shivaji nagar, Annaivelakani nagar, and the point near the northeastern side of waste stabilization pond at $3,920 \mu \mathrm{S} / \mathrm{cm}, 3,210 \mu \mathrm{S} / \mathrm{cm}$, and 3,980 $\mu \mathrm{S} / \mathrm{cm}$, which exceeds the prescribed limits of $2,250 \mu \mathrm{S} / \mathrm{cm}$ - indicating highly saline water unfit for irrigation $[20,21]$.

High chloride concentrations were observed at all wells except Megamudiyarkulam sastha in the western side of the dump yard, and the values are in the range of 250-895 mg/l. The standard for this parameter for drinking purposes is $250 \mathrm{mg} / \mathrm{l}$. Beyond this limit, taste, corrosion, and palatability are affected [22]. High chloride concentration indicates that the groundwater is affected by the dumpsite leachates.

In all wells, alkalinity values are in the range of 432-845 $\mathrm{mg} / \mathrm{l}$, which is above the standard limit of $200 \mathrm{mg} / \mathrm{l}$. The taste becomes unpleasant beyond the limit of the standards.

Sulphate concentrations in bore wells were found to be less than $200 \mathrm{mg} / \mathrm{l}$, which is within the standard limit of $200 \mathrm{mg} / \mathrm{l}$ (except in two wells in which the sulphate concentrations were less than $260 \mathrm{mg} / \mathrm{l}$ ). This causes gastrointestinal irritation beyond the standard limit when magnesium and sodium are present $[23,24]$. Except in those two wells, the tested values in all the wells are within limits.

Iron concentrations in all the wells are in the range 0.05 $0.2 \mathrm{mg} / \mathrm{l}$ - below the standard limit of $0.3 \mathrm{mg} / \mathrm{l}$.

\section{Acknowledgements}

The authors are thankful to the principal and the head of Department of Civil Engineering, Government College of Engineering Tirunelveli for Laboratory facilities.

\section{Conclusion}

In the study area at Ramayanpatti, the groundwater quality shows increased values of some physico-chemical parameters that exceed the permissible limits of the standards. Groundwater quality is generally not suitable for drinking and other domestic applications, which is revealed from the parameters examined. It is also not suitable for vegetation since the conductivity values are very high and, in addition, higher concentrations of chlorides were also present.

The area on the northeastern side of the waste stabilization pond, namely Annaivelankani nagar and the Shivajinagar, is most affected by leachate infiltrations in the groundwater. Annaivelankani nagar is in the northeastern side of the waste stabilization pond affected by wastewater infiltration. Shivaji nagar is located in a low-lying area northeast of the dumpsite and is most affected by infiltration of leachate into the groundwater aquifer.

The present work shows that the dumpsite leachates constitute a serious hazard to the local aquifer. To minimize the impact of such leachates on groundwater quality and the environment in general, it is necessary to properly design, construct, and manage the dumpsite facilities using engineering principles to prevent pollution. Regular monitoring of groundwater in that region is required and essential for a longer period in order to verify the influence of seasonal variations on contaminant concentrations. The importance of groundwater is recognized well in Tamil Nadu, India, and this resources must be protected as it is the major available source of water for domestic and irrigation purpose in this region.

\section{References}

1. BUTT I., GHAFFAR A. Ground water quality assessment near Mehmood boti landfill, Lahore, Pakistan. Asian Journal of Social Sciences \& Humanities 1, (2), 13, 2012.

2. RAJKUMAR N., SUBRAMANI T., ELANGO L. Impact of leachate on ground water pollution due to non- engineered municipal solid waste landfill sites of erode city, Tamil Nadu, India. Iranian Journal of Environmental Health Science \& Engineering. 9, (35), 1, 2012.

3. CHATTERJEE R. Municipal solid waste management in Kohima city-India. Iranian Journal of Environmental Health Science \& Engineering 7, (2), 173, 2010.

4. ALILE O M., JEGEDE S I., EMEKEME R E. Subsurface probe and hydrochemical analysis for the purpose of siting waste landfill. African Journal of Environmental Science and Technology, 4, (1), 1, 2010.

5. CHANDRASEKAR N., SIVASUBRAMANIAN P., SOUNDRANAYAGAM J. P. Ecological consequences of rapid urban expansion, Tirunelveli, India. African Journal of Basic \& Applied Sciences 2, (5-6), 167, 2010.

6. BALACHANDRAN A. Technical report series- district ground water brochure Tirunelveli district, Tamil Nadu, Central ground water board ministry of water resources government of India. 1-19, 2009.

7. ABDULLAHI N. K., OSAZUWA I. B., ONUGBA A. Detecting municipalsolid waste leachate plumes through electrical resistivity survey and physio-chemical analysis of groundwater samples. Journal of American Science 6, (8), 540, 2010.

8. ALILE O.M., OJUH D.O., IYOHA A., EGEREONU J.C. Geoelectrical investigation and hydrochemical analysis of 
groundwater in a waste dump environment, Isolo, Lagos., African Journal of Environmental Science and Technology, 5, (10), 795, 2011

9. EHIRIM C N., EBENIRO J O., OGWU D A. A geophysical and hydro-physiochemical study of the contaminant impact of a solid waste landfill (SWL) in port Harcourt municipality, Nigeria. The Pacific Journal of Science and Technology. 10, (2), 596, 2009.

10. OGUNGBE A.S., ONORI E O., OLAOYE M.A. Application of electrical resistivity techniques in the investigation of groundwater contamination: A case study of IleEpo Dumpsite, Lagos, Nigeria. International Journal of Geometrics and Geosciences, 3, (1), 30, 2012.

11. APHA 21st Eds.1998, Standard methods for the examination of water and waste water. American public health Association., Washington, DC. 1998.

12. APHA-AWWA-WPCF $15^{\text {th }}$ Eds. 1994 standard methods for the examination of water and waste water, American public health. 1994.

13. NWAGBARA J. O., NWUGHA, V. N., ULOR M. O. Electrical resistivity study for vulnerability of groundwater pollution: A casestudy of land fill dumpsites in OWERRI, IMO state. International Journal of Emerging Trends in Engineering and Development. 2, (4), 17, 2012.

14. SOUPIOS P., PAPADOPOULOS I., KOULI M., GEORGAKI I., VALLIANATOS F., KOKKINOU E. Investigation of waste disposal areas using electrical methods: case study from Chania, Crete, Greece. Environ. Geol. 2006.

15. AKANKPO A. O., IGBOEKWE M. U. Monitoring groundwater contamination using surface electrical resistivity and geochemical methods. Journal of Water Resource and Protection, 3, 318, 2011.
16. BIS, (1994); Indian Standards Specifications for Drinking Bureau of Indian Standards, IS:10500-1994.

17. DZIK A. J. Cerebrovascular Disease mortality rates and water hardness in North Dakota. South Dakota. J. Med., 42, (4), 5, 1989.

18. ANZECC, Australian and New Zealand Environment and conservation council, Water quality guide lines. 2000.

19. WHO (World Health Organization) guideline for drinking water quality $2^{\text {nd }} \mathrm{ed}$. Vol 2 . Health criteria and other supporting information, world Health Organization, Geneva, 2, 940, 1977.

20. RICHARD L.A. Diagnosis's improvement of saline and alkali soils. Hand book no.60, U.S department of agriculture, Washington, D.C, Water. The year book of agriculture, oxford and IBH publisher, New Delhi, 955, 1954.

21. AWOFOLU O R., DUPLESSIS R., RAMPEDI I. Influence of discharge effluent on water quality of surface water utilized for Agricultural purposes. African Journal of Biotechnology 6, 2251, 2007.

22. HANSER B A. Drinking water chemistry: A laboratory manual: Lewis publishers ACRC press company Boca Raton FL-2001.

23. BERTRAM J., BALANEE R. A Practical guide to the design and implementation of fresh water quality studies and monitoring programme. United Nations Environmental Programmes (UNEP) and World Health Organization (WHO), E and FN spoon publishers. 172-177, 1996.

24. BUNDELA P. S., SHARMA A., PANDEY A. K., PANDEY P., AWASTHI A. K. Physicochemical Analysis of ground water near municipal solid waste dumping sites in Jabalpur. International Journal of Plant, Annual and Environmental Science., 2, (1), 217, 2012. 